\title{
Performance of Acacia mangium-Cow Pea Based Agroforestry System in North Central Plateau Zone of Odisha
}

\author{
G. Shial $1^{*}$, U. S. Nayak ${ }^{2}$ and K. Upadhyay ${ }^{3}$ \\ ${ }^{1}$ Krishi Vigyan Kendra (OUAT), Bhadrak, Odisha (756 111), India \\ ${ }^{2}$ Regional Research and Technology Transfer Station (OUAT), Ranital, Odisha (756 111), India \\ ${ }^{3}$ School of Earth Science \& Natural Resource Management, Mizoram University, Tanhril (796 004), India
}

\section{Corresponding Author}

G. Shial

e-mail: gayadharbalasore@gmail.com

\author{
Article History \\ Article ID: AR1846f \\ Received in $25^{\text {th }}$ September, 2017 \\ Received in revised form $5^{\text {th }}$ October, 2017 \\ Accepted in final form $7^{\text {th }}$ October, 2017
}

\begin{abstract}
Field experiments carried out to assess the performance of Acacia mangium-Cow pea based agroforestry system and their interactive effects on the growth of tree species and yield of intercrop at Keonjhar district of Odisha during 2010 to 2012 . The results indicated that the growth and establishment of Acacia mangium plants were found to be superior in the intercropped plots than the un-cropped plots. At 36 months after planting, the Acacia mangium plants under agro-forestry system registered better crop growth (7.68 $\mathrm{m}$ height, 12.88 $\mathrm{cm} \mathrm{DBH}, 3.45 \mathrm{~m}$ crown spread, 32.34 no. of branches plant $\mathrm{t}^{-1}, 0.092 \mathrm{t} \mathrm{ha}^{-1}$ pruned biomass) as compared to the pure crop (7.14 $\mathrm{m}$ height, $12.45 \mathrm{~cm} \mathrm{DBH}, 3.34 \mathrm{~m}$ crown spread, 31.78 no. of branches plant ${ }^{-1}$ and $0.086 \mathrm{t} \mathrm{ha}^{-1}$ pruned biomass). The yield of cow pea as intercrop was

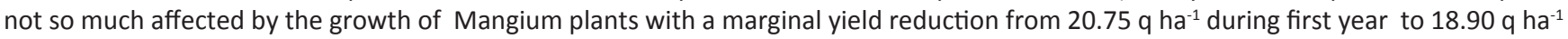
in the $3^{\text {rd }}$ year. The Acacia mangium-cow pea agroforestry system also resulted in an additional return of ₹ 9050.00 ha $^{-1}$ during the first year to ₹ 7200.00 ha $^{-1}$ during the third year from the harvest of cow pea. Hence, growing cow pea in the interspaces of Acacia mangium tree can be an ideal agroforestry system for the rainfed upland regions of this agro-climatic zone
\end{abstract}

Keywords: Agro-forestry, Acacia mangium, cow pea

\section{Introduction}

Agroforestry continues to support livelihood improvement through production of food, fodder, fuel wood and timber and simultaneous mitigation of the adverse impact of climate change (Islam and Quli, 2016). Particularly the upland eco-system is prone to recurrent moisture stress and drought like situations and therefore requires a suitable agro-forestry system to increases the overall productivity of the land through judicious combination of perennial trees with seasonal crops. The tree crop combination insulate the resource poor small holders from total crop failure and provide a wide range of eco-system benefits like prevention of land degradation, restoration soil health and suppression of weed flora. Keonjhar district of Odisha coming under North central Plateau Agro-climatic zone of the state has a vast track of upland and undulating topography. Agricultural crops grown in the eroded uplands suffer from water stress during critical stages of crop growth. The nature and extent of problem warrants for intervention of tree based diversified farming system where the tree component can maintain soil fertility through recycling of nutrients, prevents soil erosion and loss of nutrients through runoff and leaching and the seasonal crops smother weed growth and enhance the microbial activity in the soil. Acacia mangium, a fast growing and nitrogen fixing tree species bears tremendous prospects for the hilly and undulating areas of Keonjhar districts. Tropical tree like Acacia mangium are commonly used for plantations as these species have high early growth rates, are adapted to harsh environments and being legumes can fix nitrogen (Brockwell et al., 2005). In addition to its other benefits like fast growth, easy decomposition of leaf litter, good coppicing ability, early harvest (after 10-12 years of growth), good timber value, it is a good carbon sink and has great carbon sequestration potential. Keeping this in view, Acacia mangium-cow pea based agro-forestry system was evaluated in the uplands of Keonjhar district to assess the effect of intercrops on the growth and development of tree species up to 36 months after planting and the overall productivity and profitability of the system.

\section{Materials and Methods}

A field experiment was carried out in the farmers' field of 
Jamunaposi village of Keonjhar district of Odisha, India during the year 2010 to 2012 . The experimental site was situated in the well drained rainfed upland with sandy loam soil texture. The two treatments i.e. Acacia mangium with cow pea as intercrop and a sole plantation of Acacia mangium were laid out in Randomized Block Design with thirteen replications and each farmer represent one replication. One year seedlings of Acacia mangium planted in $30 \times 30 \times 30 \mathrm{~cm}^{3}$ pit at a closer spacing of $2 \times 2 \mathrm{~m}^{2}$ to deter occurring of epicormic branches during July 2010. Cowpea var. Utkal Manika was sown as inter crop in the alleys of trees with usual agronomic management practices and standard intercultural operations. Cow pea was sown once in a year during kharif season under rainfed condition. All the recommended silvicultural practices were followed for maintaining of plantations. The observations viz. plant height, Diameter at Breast Height (DBH), crown spread, no. of branches ${ }^{-1}$ plant and pruned biomass were recorded form both the intercropped and uncropped areas form 6 months after planting (MAP) to 36 MAP in 6 months interval. Cow pea yield and net income were also recorded during these periods.

\section{Results and Discussion}

The performance of Acacia mangium-Cow Pea Based AgroForestry System assessed during the 2010 to 2012 indicated that the mean height, $\mathrm{DBH}$, crown spread, branches and pruned bio mass increased with increase of age of the tree component and the increase of these growth parameters were higher in the tree crop integration system than in the pure plant stand (Table 1). At 6 MAP the average height of $A$. mangium sapling under agro-forestry system was found to be $1.38 \mathrm{~m}$, whereas, that of as sole crop was $1.30 \mathrm{~m}$. Similarly, the average $\mathrm{DBH}$ of plants with and without intercrops were estimated to be 1.96 and $1.92 \mathrm{~cm}$, respectively. The crown spread and average number of branches plant ${ }^{-1}$ were found to be higher in the agro-forestry systems (0.895 $\mathrm{m}$ and 10.85 , respectively) as compared to the sole crops (0.785 $\mathrm{m}$ and 9.95, respectively). A similar trend was also observed at 12, 18, 24 and 30 MAP and the saplings of Acacia mangium registered better crop growth under agro-forestry system than as pure crop. At 36 MAP, the Mangium plant in the intercropping system was found to be taller $(7.68 \mathrm{~m})$, thicker $(12.88 \mathrm{~cm})$ with larger crown spread (3.45 m), higher number of branches plant $^{-1}(32.34)$ and more pruned biomass $\left(0.092 \mathrm{t} \mathrm{ha}^{-1}\right)$ than as pure crop (7.14 m height, $12.45 \mathrm{~cm} \mathrm{DBH,} 3.34 \mathrm{~m}$ crown spread, 31.78 number of branches plant ${ }^{-1}$ and $0.086 \mathrm{t} \mathrm{ha}^{-1}$ pruned biomass). The better growth performance of Acacia mangium in the agro-forestry system might be attributed to lower weed growth, better nutrient management through Nitrogen fixation by cow pea and nutrient recycling, better moisture conservation and higher microbial activity in the soil due to larger organic carbon content obtained from the biomass of the intercrop. During the period of investigation, it was also observed that the yield of cow pea as intercrop was not so much affected by the growth of Mangium plants with a marginal yield reduction from $20.75 \mathrm{q} \mathrm{ha}^{-1}$ during first year to $18.90 \mathrm{q} \mathrm{ha}^{-1}$ in the $3^{\text {rd }}$ year. The marginal reduction in cow pea yield at third of planting might be due to the increasing canopy growth of tree and subsequent shade effect. The Acacia mangium- cow pea agro-forestry system also resulted in an additional return of $₹ 9050.00 \mathrm{ha}^{-1}$ during the first year to $₹ 7200.00 \mathrm{ha}^{-1}$ during the third year from the harvest of cow pea.

The results of the experiment derived ample support from the findings of Gantayat et al., 2008 and Mohapatra et al., 2008, who also opined that the growth and establishment of Acacia mangium was better under agro-forestry system than the sole crop. Vanlalhluna and Sahoo, 2009 also opined that the plants under cropped area were relatively taller and thicker in comparison to the uncropped area might be due to higher soil moisture regime and better microclimatic condition favouring growth performances. According to Dhamodaran and Chacko (1999) Acacia mangium has been popularly planted in most districts of Kerala in private farms either in conjunction with other farm crops or as pure plantations of varying sizes and has a great acceptance among the farmers. Nayak et al. (2014) also opined that Acacia mangium (Mangium) is very much suitable for the agrisilvicultural system in rainfed uplands of Odisha and the maximum volume increment were achieved by Mangium with Pineapple $\left(16.53 \mathrm{~m}^{3} \mathrm{ha}^{-1}\right)$ with a maximum

Table 1: Growth attributes of Acacia mangium with and without cowpea under farmers' field condition during 2010-12

\begin{tabular}{|c|c|c|c|c|c|c|c|c|c|c|c|c|}
\hline \multirow[t]{2}{*}{ Characters } & \multicolumn{2}{|c|}{$6 \mathrm{MAP}$} & \multicolumn{2}{|c|}{12 MAP } & \multicolumn{2}{|c|}{$18 \mathrm{MAP}$} & \multicolumn{2}{|c|}{$24 \mathrm{MAP}$} & \multicolumn{2}{|c|}{$30 \mathrm{MAP}$} & \multicolumn{2}{|c|}{36 MAP } \\
\hline & WT & WOC & WT & WOC & WT & WOC & WT & WOC & WT & WOC & WT & WOC \\
\hline Height (m) & 1.38 & 1.3 & 3.64 & 3.52 & 4.16 & 4 & 5.68 & 5.35 & 7.26 & 6.85 & 7.68 & 7.14 \\
\hline $\mathrm{DBH}(\mathrm{cm})$ & 1.96 & 1.92 & 3.19 & 3 & 7.78 & 7.65 & 9.36 & 9.22 & 12.34 & 11.95 & 12.88 & 12.45 \\
\hline Crown spread (m) & 0.895 & 0.785 & 1.18 & 1.12 & 2.17 & 2.1 & 2.43 & 2.32 & 3.13 & 3 & 3.45 & 3.34 \\
\hline No. of branches & 10.85 & 9.95 & 11.9 & 11.22 & 21.54 & 20.68 & 23.8 & 22.97 & 27.56 & 26.58 & 32.34 & 31.78 \\
\hline Pruned biomass (t ha-1) & - & - & 0.082 & 0.079 & 0.084 & 0.08 & 0.085 & 0.082 & 0.087 & 0.083 & 0.092 & 0.086 \\
\hline Intercrop yield ( $q$ ha $^{-1}$ ) & 20.75 & & & & 20.1 & & & & 18.9 & & & \\
\hline Net income (₹ ha-1) & 9050 & & & & 8400 & & & & 7200 & & & \\
\hline
\end{tabular}

WC: With crop; WOC: Without crop 
pine apple fruit yield of $9981 \mathrm{~kg} \mathrm{ha}^{-1}$.

\section{Conclusion}

Mangium being a deep rooted and nitrogen fixing plant proved to an ideal plant for multi-tier cropping system. The yield of cow pea grown in the initial 3 years in the inter space were not significantly affected by the growth of Mangium. The height, DBH and other growth attributes was higher in inter cropped area as compared with pure plantation of Mangium. Therefore, cultivation of cow pea in association with Acacia mangium tree may be an ideal combination for the rainfed upland regions of this Agro-climatic zone.

\section{References}

Brockwell, J., Searle, S.D., Jeavons, A.C., Waayers, M., 2005. Nitrogen fixation in Acacias: an untapped resource for sustainable plantations, farm forestry and land reclamation. ACIAR Monograph, Canberra.

Dhamodaran, T.K., Chacko, K.C., 1999. Growth and wood characteristics of Acacia mangium grown in Kerala. KFRI Research Report 174, 45.
Gantayat, B.P., Mohapatra, A.K., Swain, D., Das, S., 2008. Relative performance of tree species suitable for agroforestry systems in coastal Orissa. Journal of Research, Orissa University of Agriculture and Technology 26(1), 10-13.

Islam, M.A., Quli, S.M.S., Sofi, P.A., Bhat, G.M., Malik, A.R., 2015. Livelihood Dependency of Indigenous People on Forest in Jharkhand, India. Vegetos 28(3), 106-118.

Mohapatra, A.K., Gantayat, B.P., Patra, A.K., Swain, D., 2008. Performance of Acacia mangium based agroforestry systems in East and South Eastern coastal plain zone of Orissa. Journal of Research, Orissa University of Agriculture and Technology 26(2), 48-52.

Nayak M.R., Behera L.K., Mishra P.J., Bhola, N., 2014. Economics and yield performance of some short duration fruit and medicinal crops under agrisilvicultural system in rainfed uplands of Odisha. Journal of Applied and Natural Science 6 (1), 274-278.

Vanlalhluna, P.C., Sahoo, U.K., 2009. Performance of multipurpose trees and the associated crops in agroforestry system of Mizoram. Indian Journal of Forestry 32(2), 191-194. 